\title{
Prognostic significance of serum potassium level for major adverse cardiac events and death in patients with coronary atherosclerotic disease
}

\author{
Afrasyab Altaf', Aftab Alam', Momin Salahuddin², Momin Khan', Mazhar Mahmood', \\ Hammad Shah ${ }^{3}$, Karamat Ali Shah ${ }^{2}$ \\ 'Assistant Professor, Cardiology Department, Rehman Medical Institute, Peshawar, Pakistan \\ ${ }^{2}$ Professor, Cardiology Department, Rehman Medical Institute, Peshawar, Pakistan \\ ${ }^{3}$ Fellow in Training, Cardiology Department, Rehman Medical Institute, Peshawar, Pakistan
}

\begin{abstract}
Introduction: Serum potassium levels have been shown in some animal studies to be associated with the process of atherosclerosis. We decided to assess the correlation of serum potassium level in ischemic heart disease patients with disease severity and its relationship with prognosis in terms of major acute cardiac events (MACE). Material and methods: This was a cross-sectional cohort study carried out at cardiology department of Rehman Medical Institute, from July 2016 to $31^{\text {st }}$ Aug. 2018 a period of 26 months. 622 patients were included in the study. Clinical and angiographic characteristics were assessed based on the serum potassium level. Correlation of serum potassium level with Synergy between Percutaneous Coronary Intervention with Taxus and Cardiac Surgery (SYNTAX) and Gensini scores was also evaluated. Follow up for MACE was carried out after one year.

Results: Mean serum potassium level was $3.93 \pm 0.95$ (mEq/l) in coronary artery disease patients. Serum potassium level showed negative correlation with SYNTAX score $(r=-0.60, p<0.05)$ and Gensini score $(r=-0.64, p<0.05)$. There was also a significant difference between low and high potassium level in relation to the multi-vessel disease on coronary angiography $(p<0.05)$. Low potassium level was a good predictor of adverse outcomes as shown by Kaplan-Meier analysis. Multivariate Cox regression analysis showed that serum potassium level and diabetes were independent predictors of MACE $(p<0.05)$.
\end{abstract}

Conclusion: Low serum potassium level is correlated with more severe coronary atherosclerosis. Low potassium levels are associated with significantly poor outcomes.

Key words: coronary artery disease, coronary angiography, prognosis, potassium

Acta Angiol 2020; 26, 2: 58-64

\section{Introduction}

Cardiovascular disease is the leading cause of morbidity and mortality globally [I]. A lot of research is underway to better understand the causes of cardiovascular disease as well as the means to reduce such an alarming incidence. One such modifiable factor which has come under light recently is serum potassium level.
Hypokalemia has multiple effects on the myocardium and predisposes to arrhythmias while on the other hand hyperkalemia slows down conduction [2].

Studies have shown that elevated potassium levels induce arterial smooth muscle relaxation and cause vasodilatation due to involvement of $\mathrm{K}+$ channels and $\mathrm{Na}+/ \mathrm{K}+-$ ATPase [3-6]. Elevated serum potassium levels also play a role in the inhibition of platelet ag- 
gregation and arterial thrombus formation, and hence coronary atherosclerosis [7-10].

However, a few recent studies [ I I, I 2] have demonstrated the correlation between elevated serum potassium levels and increased atherosclerosis as well as the severity of coronary artery disease, which would contradict the above-given explanations. So, keeping in mind the results of such studies, we hypothesized that lower serum potassium may be associated with an increased risk of cardiovascular events and mortality.

\section{Material and methods}

This was a cross-sectional (for correlation) and cohort (for MACE) study carried out at cardiology department of Rehman Medical Institute, Peshawar, which is one of the biggest tertiary care hospitals in KPK, Pakistan providing $24 / 7$ cath. lab facility, from July 2016 to August 2018 , a period of 26 months. A total of 622 patients were included in the study population using universal sampling technique. All those patients were included who gave consent for inclusion and were admitted or discharged with the diagnosis of ischemic heart disease fulfilling the criteria of either stable angina, unstable angina or myocardial infarction [13]. Patients who were admitted due to non-cardiac causes like severe pneumonia, ARDS, and renal failure were excluded from the study population. All baseline demographic characteristics including age, gender, diabetes, hypertension, body mass index (BMI), smoking, alcohol consumption, and medication use were noted for each patient from history and hospital records. For measured variables, blood samples were taken at admission and sent for analysis of serum potassium, hemoglobin level, troponin level, CRP level, creatinine, and urea, total cholesterol (TC), low-density lipoprotein cholesterol (LDL), triglyceride (TG), high-density lipoprotein cholesterol (HDL) levels (Cobas B22I and 6000 , Roche-Switzerland). All cases were divided into two groups (Low and High potassium groups) based on median serum potassium levels.

\section{Definition of risk factors and clinical syndromes}

Hypercholesterolemia was diagnosed in patients who had been given lipid-lowering medication or had a history of total cholesterol levels $>200 \mathrm{mg} / \mathrm{dl}$ [ [4]. Patients were diagnosed as hypertensive if they were documented to have a systolic blood pressure $140 \mathrm{~mm} \mathrm{Hg}$ or a diastolic blood pressure $90 \mathrm{~mm} \mathrm{Hg}$ on more than two occasions (but not during the angiogram procedure) or were already on antihypertensive therapy [15]. Patients were diagnosed with diabetes mellitus if they had a documented fasting glucose value $>126 \mathrm{mg} / \mathrm{dl}$ or $\mathrm{HbAIC}$ of $>7$ on one or more occasion or were tak- ing insulin or oral hypoglycemic medications for diabetes mellitus. Myocardial infarction (MI) on presentation was diagnosed by a history of chest pain, electrocardiogram showing new ST-segment/T wave changes or new pathological $Q$ waves or new left bundle branch block (LBBB), echocardiographic evidence of new regional wall motion abnormality and two recordings of hs-troponin levels showing rise and/or fall in values with at least one value above $99^{\text {th }}$ percentile upper reference limit (URL). Body mass index was calculated by dividing the weight of the patient in kilograms by the square of height in meters. Active Smokers were defined as someone who smoked $>100$ cigarettes, cigars, or pipes in their lifetime and still smoked in the last 28 days. Smokers were classified as former only if they had smoked > 100 cigarettes, cigars, or pipes in their lifetime and has not smoked in the last 28 days preceding the date of angiography [16].

\section{Angiographic evaluation}

Coronary angiography was performed with Seldinger technique in all the patients [17]. All angiographic assessments were done by two independent cardiologists. In case of difference in opinion, a third cardiologist was consulted. Patients were then divided into a control group (normal coronary vessels) and cases group (coronary arteries with the disease). Control group included 100 subjects and 622 cases with coronary artery stenosis $\geq 50 \%$ of the vessel diameter were included in the CAD group (622 cases: 371 men and 25 I women). SYNTAX and Gensini scoring systems were used to assess the severity of coronary stenosis in all cases. In SYNTAX score calculation each coronary lesion producing $\geq 50 \%$ diameter stenosis in vessels $\geq 1.5 \mathrm{~mm}$ was scored separately using the SYNTAX score algorithm available on the Internet from the and added to obtain the overall SYNTAX score. Gensini score is based on the severity of lesion narrowing, number of lesions, lesion location, and influence of collaterals [18, 19].

Major adverse cardiac events (MACE) for the purposes of follow-up were as follows: (I) acute myocardial infarction; (2) decompensated heart failure; (3) target vessel revascularization and (4) mortality due to cardiac disease [20].

This study was evaluated and approved by the Research evaluation and Ethics Committee of Rehman Medical Institute. The study abided by the principles of the Declaration of Helsinki. Written and informed consent was obtained from each patient included in the study.

\section{Statistical analysis}

Data were analyzed for normality using the Kolmogorov-Smirnov (KS) test. Continuous data are presented 
Table I. Baseline characteristics and angiographic features of study groups based on serum potassium levels

\begin{tabular}{|c|c|c|}
\hline Variable & Serum potassium $(<4 \mathrm{mEq} / \mathrm{l})$ & Serum potassium ( $4 \mathrm{mEq} / \mathrm{l}$ or above) \\
\hline Number of patients & 349 & 273 \\
\hline Age (years) & $63.72 \pm 4.35$ & $62.54 \pm 10.23$ \\
\hline Gender (m/f) & $210 / 139(60 / 40 \%)$ & $161 / 112(59 / 41 \%)$ \\
\hline Ejection fraction (\%) & $49.98 \pm 10.55$ & $49.87 \pm 10.35$ \\
\hline Blood sugar & $|47.3| \pm 96.06$ & $146.40 \pm 80.14$ \\
\hline Serum creatinine & $1.01 \pm 0.23$ & $1.01 \pm 0.22$ \\
\hline Hemoglobin (g/dl) & $14.2 \pm 1.7 \mid$ & $14.39 \pm 1.72$ \\
\hline $\mathrm{BNP}(\mathrm{pg} / \mathrm{ml})$ & $395.12 \pm 629.35$ & $487.12 \pm 800.72$ \\
\hline Hs-Troponin & $3443 \pm 4414$ & $4584 \pm 5796$ \\
\hline CRP & $8.00 \pm 11.19$ & $7.91 \pm 10.59$ \\
\hline Diabetes & $122(35 \%)$ & $85(31 \%)$ \\
\hline Hypertension & $192(55 \%)$ & $158(58 \%)$ \\
\hline Smoking & $105(30 \%)$ & $90(33 \%)$ \\
\hline Hyperlipedemia & $98(28 \%)$ & $68(25 \%)$ \\
\hline Anti-Platelet drugs & $345(99 \%)$ & $273(100 \%)$ \\
\hline Beta blocker & $311(89 \%)$ & $235(86 \%)$ \\
\hline RAAS inhibitors & $195(56 \%)$ & $145(53 \%)$ \\
\hline Nitrates & $188(54 \%)$ & $156(57 \%)$ \\
\hline Digoxin & $70(20 \%)$ & $49(18 \%)$ \\
\hline Diuretics & $70(20 \%)$ & $46(17 \%)$ \\
\hline Lipid lowering agents & $209(60 \%)$ & $169(62 \%)$ \\
\hline SYNTAX score & $37.48 \pm 7.28$ & $26.76 \pm 6.34 *$ \\
\hline Gensini score & $77.56 \pm 13.05$ & $56.46 \pm 12.24 *$ \\
\hline Multi-vessel disease & $174 /(50 \%)$ & $96 /(35 \%)^{*}$ \\
\hline LAD & $220 /(63 \%)$ & $150 /(55 \%)$ \\
\hline LCX & $157 /(45 \%)$ & $109 /(40 \%)$ \\
\hline RCA & $132 /(38 \%)$ & $93 /(34 \%)$ \\
\hline
\end{tabular}

*P $\leq$ 0.05; CRP: C-reactive protein; RAA: renin angiotensin aldosterone system inhibitors; LAD: left anterior descending artery; LCX: left circumflex artery; RCA: right coronary artery

as means \pm SD Between-group comparisons were performed using t-test. Categorical data were presented as percentages and analyzed using $\chi^{2}$ test. The correlation between serum potassium level, Syntax and Gensini scores were examined by Pearson correlation analysis. and Kaplan Meyer analysis was used for survival analysis. Differences with $\mathrm{p}$ values $<0.05$ were considered statistically significant. Multivariate Cox regression analysis was done to examine the independent predictors of MACE

\section{Results}

\section{General clinical data comparison}

Mean serum potassium level was $3.93 \pm 0.95(\mathrm{mEq} / \mathrm{l})$ in coronary artery disease patients. Patients were divided based median serum potassium level $(4 \mathrm{mEq} / \mathrm{l})$ and comparison was made of baseline characteristics. There were no significant differences in clinical characteristics at baseline between the two groups with high and low potassium levels $(p>0.05)$ (Table I). All patients received similar medication such as anti-platelets, beta-blockers, Renin Angiotensin Aldosterone system (RAAS) inhibitors, statins, nitrates and diuretics. Patients' characteristics with and without MACE were also compared which showed a significant difference in serum potassium level, BMI, ejection fraction, SYNTAX score, Gensini Score and multi-vessel disease $(p \leq 0.05)$ (Table 2).

\section{Angiographic assessment and correlation}

Angiographic analysis based on serum potassium level demonstrated that there was a significant difference 
Table 2. Patient characteristics and angiographic features of study groups according to MACE

\begin{tabular}{|c|c|c|}
\hline Variable & Patients without MACE & Patients with MACE \\
\hline Number of patients & 601 & 21 \\
\hline Age (years) & $61.35 \pm 5.62$ & $63.32 \pm 8.46$ \\
\hline Gender (m/f) & $330 / 27 I(55 / 45 \%)$ & $12 / 9(60 / 4 \mid \%)$ \\
\hline Serum potassium $(<4 \mathrm{mEq} / \mathrm{l})$ & $3.38 \pm 0.44$ & $4.62 \pm 0.56^{*}$ \\
\hline BMI & $22.43 \pm 1.12$ & $25.11 \pm 1.15^{*}$ \\
\hline Ejection fraction (\%) & $54.51 \pm 8.14$ & $42.35 \pm 7.29 *$ \\
\hline Blood sugar & $|40.3| \pm 87.27$ & $148.40 \pm 72.44$ \\
\hline Serum creatinine & $1.11 \pm 0.35$ & $1.23 \pm 0.28$ \\
\hline Hemoglobin $(\mathrm{g} / \mathrm{dl})$ & $13.4 \pm 1.53$ & $14.38 \pm 1.67$ \\
\hline $\mathrm{BNP}(\mathrm{pg} / \mathrm{ml})$ & $346.19 \pm 601.45$ & $501.17 \pm 780.58$ \\
\hline Hs-troponin & $3566 \pm 3942$ & $4731 \pm 5385$ \\
\hline CRP & $6.00 \pm 9.12$ & $8.34 \pm 11.89$ \\
\hline Diabetes & $222(37 \%)$ & $13(62 \%)^{*}$ \\
\hline Hypertension & $30 I(50 \%)$ & $12(57 \%)$ \\
\hline Smoking & $186(31 \%)$ & $7(35 \%)$ \\
\hline Hyperlipedemia & 144 (24\%) & $6(29 \%)$ \\
\hline Anti-platelet drugs & $601(100 \%)$ & $20(95 \%)$ \\
\hline Beta blocker & $54 I(90 \%)$ & $18(86 \%)$ \\
\hline RAAS inhibitors & $330(55 \%)$ & II (54\%) \\
\hline Nitrates & $330(55 \%)$ & $12(57 \%)$ \\
\hline Digoxin & $108(18 \%)$ & $4(20 \%)$ \\
\hline Diuretics & $150(25 \%)$ & $6(30 \%)$ \\
\hline Lipid lowering agents & $360(60 \%)$ & $13(62 \%)$ \\
\hline SYNTAX score & $25.48 \pm 6.24$ & $39.76 \pm 7.37^{*}$ \\
\hline Gensini score & $57.56 \pm 12.16$ & $79.46 \pm 10.43 *$ \\
\hline Multi-vessel disease & $204 /(34 \%)$ & I2/(57\%)* \\
\hline LAD & $348 /(58 \%)$ & $13 /(62 \%)$ \\
\hline LCX & $288 /(42 \%)$ & $9 /(43 \%)$ \\
\hline RCA & $198 /(33 \%)$ & $8 /(38 \%)$ \\
\hline
\end{tabular}

*P $\leq$ 0.05; CRP: C-reactive protein; RAA: renin angiotensin aldosterone system inhibitors; LAD: left anterior descending artery; LCX: left circumflex artery; RCA: right coronary artery

between low and high potassium level groups in terms of multi-vessel disease, SYNTAX score and Gensini score $(p<0.05)$. The involvement of the type of vessel was similar in both groups ( $p>0.05)$ (Table I).

The mean SYNTAX score all patients was $32.78 \pm$ 8.70 while the Gensini score was $68.30 \pm 16.46$. The results of Pearson's correlation indicate that there was a significant negative correlation between the concentration of potassium and SYNTAXscore $(r=-0.60, p<0.05)$. and Gensini score $(r=-0.64, p<0.05)$ (Fig. I).

\section{Survival and multivariate analysis for MACE}

For analysis, we assessed Kaplan-Meier curves according to median value of serum Potassium level (median
$=4 \mathrm{mEq} / \mathrm{l}$ ) (Fig. 2). The Kaplan-Meier curves revealed a significantly worse cumulative outcome in patients with serum Potassium level below $4 \mathrm{mEq} / \mathrm{l}$.

Cumulative MACE for this study was $3.4 \%$ (2I patients). The 180 days mortality was I.28\% (8 patient), myocardial infarction $1.76 \%$ (I I patients), target vessel revascularization was $1.1 \%$ (7 patients) and cardiac failure was I. I\% (7 patients) (Tables 3, 4).

\section{Discussion}

Data from the Systolic Hypertension in the Elderly Program (SHEP) [2I] trial has shown that normal potassium level has significantly reduced hazard ration 


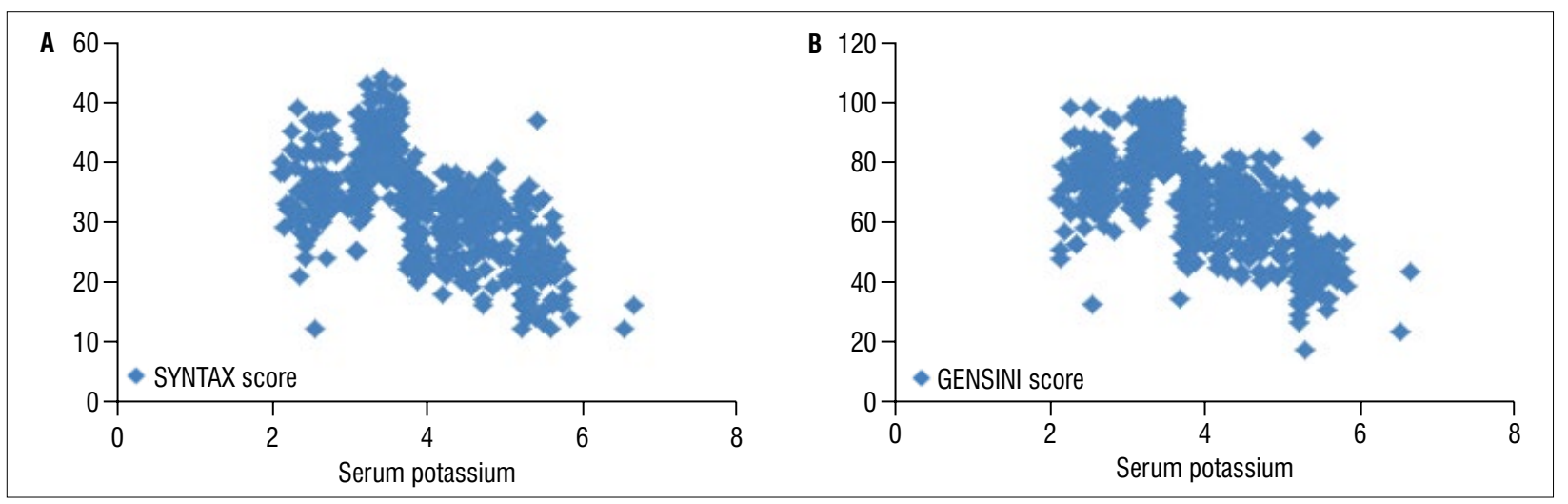

Figure I. Correlation of serum potassium level with (a) SYNTAX score and (b) Gensini score. Pearson's correlation analysis show negative correlation for both [SYNTAX score $(r=-0.06)$ and Gensini score $(r=-0.64)$ ]

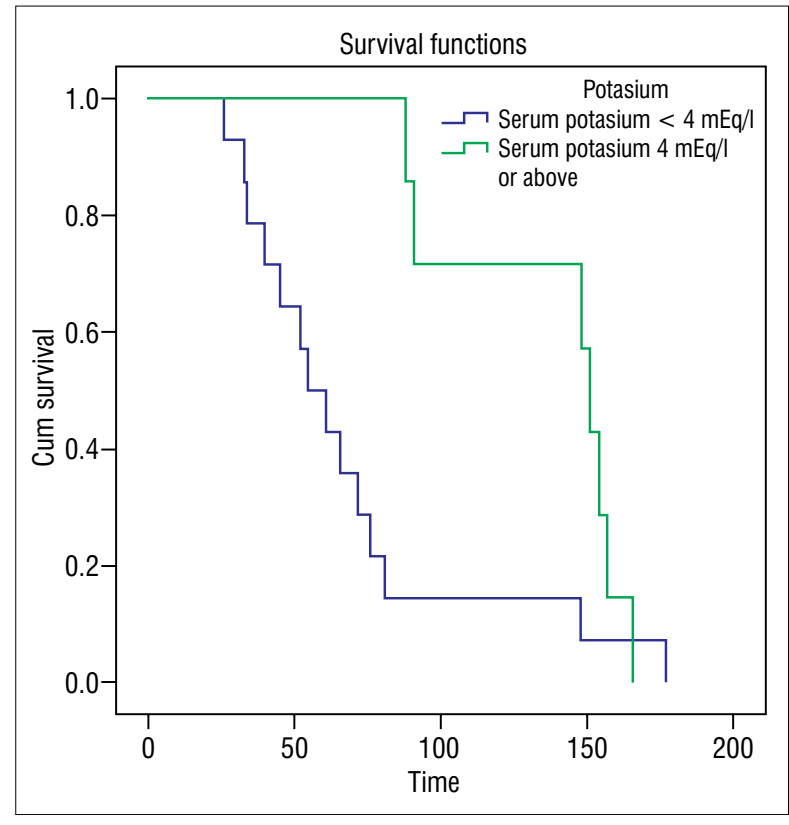

Figure 2. Kaplan Meier analysis based on median serum potassium level. A significant difference between low and high potassium for adverse outcomes $(p<0.05)$. Time in number of days

for cardiovascular events including stroke and coronary vessels related events. Moreover, animal studies have shown that high potassium diets normalize blood pressure and provide protection against atherosclerosis in arteries [22].

Increased potassium content in diets plays a role reduction of vascular lesions owing to decreased endothelial injuries and less adherence and infiltration of macrophages into the vascular wall [II].

Other mechanisms explaining the role of increased potassium levels in the maintenance of normal blood
Table 3. Univariate analysis for MACE

\begin{tabular}{|c|c|c|}
\hline & \multicolumn{2}{|c|}{ Univariate analysis } \\
\hline & HR $(95 \% \mathrm{Cl})$ & p value \\
\hline Gender (M vs. F) & $1.131(0.151-3.167)$ & 0.31 \\
\hline Age $(\geq 60$ vs. $<60)$ & $0.519(0.212-1.926)$ & 0.32 \\
\hline $\begin{array}{l}\text { Serum potassium } \\
(\geq 4 \mathrm{mEq} / \mathrm{l} \text { vs. }<4 \mathrm{mEq} / \mathrm{l})\end{array}$ & $1.426(1.077-1.413)$ & 0.02 \\
\hline $\begin{array}{l}\text { Ejection fraction } \\
(\geq 50 \% \text { vs. }<50 \%)\end{array}$ & $1.242(0.55 \mathrm{I}-\mathrm{I} .236)$ & 0.05 \\
\hline $\begin{array}{l}\text { Hypertension (present } \\
\text { vs. absent) }\end{array}$ & $1.986(0.191-47.626)$ & 0.45 \\
\hline $\begin{array}{l}\text { Diabetes (present } \\
\text { vs. absent) }\end{array}$ & $1.378(1.107-1.412)$ & 0.03 \\
\hline $\mathrm{BMI}(\geq 25$ vs. $<25)$ & $0.658(0.42|-| .229)$ & 0.19 \\
\hline Smoking (yes vs. no) & $1.716(0.635-66.137)$ & 0.67 \\
\hline $\begin{array}{l}\text { Total cholesterol }(\geq 200 \\
\mathrm{mg} / \mathrm{dl} \text { vs. }<200 \mathrm{mg} / \mathrm{dl})\end{array}$ & I. $109(0.229-6.443)$ & 0.75 \\
\hline $\begin{array}{l}\text { BNP }(\geq 100 \mathrm{pg} / \mathrm{ml} \text { vs. } \\
<100 \mathrm{pg} / \mathrm{ml})\end{array}$ & $0.582(0.316-1.572)$ & 0.37 \\
\hline $\begin{array}{l}\text { Troponin ( } \geq 14 \text { mg/l vs. } \\
<14 \mathrm{ng} / \mathrm{l})\end{array}$ & $0.088(0.087-1.983)$ & 0.31 \\
\hline $\begin{array}{l}\text { Creatinine }(\geq \mathrm{l} .2 \mathrm{mg} / \mathrm{dl} \\
\mathrm{vs}<\mathrm{l} .2 \mathrm{mg} / \mathrm{dl})\end{array}$ & $0.865(0.794-1.18 I)$ & 0.28 \\
\hline $\begin{array}{l}\text { Family history of } C A D^{c} \\
\text { (present vs. absent) }\end{array}$ & $1.927(0.251-59.172)$ & 0.43 \\
\hline $\begin{array}{l}\text { Multi-vessel disease } \\
\text { (present vs. absent) }\end{array}$ & $0.229(0.026-67.472)$ & 0.14 \\
\hline
\end{tabular}

BMI: body mass index; BNP: basic natriuretic peptide; CAD: coronary artery disease

pressure as well as prevention of coronary atherosclerosis are as follows; a) inhibition of platelet aggregation and arterial thrombosis; b) reduction in renal vascular resistance and increase in glomerular filtration rate; 
Table 4. Multivariate regression analysis for MACE

\begin{tabular}{|c|c|c|}
\hline & \multicolumn{2}{|c|}{ Multivariate analysis } \\
\hline & HR $(95 \% \mathrm{Cl})$ & p value \\
\hline $\begin{array}{l}\text { BMI }(\geq 100 \mathrm{pg} / \mathrm{ml} \text { vs. } \\
<100 \mathrm{pg} / \mathrm{ml})\end{array}$ & $0.48 \mathrm{I}(0.6 \mathrm{I} 3-2.754)$ & 0.54 \\
\hline $\begin{array}{l}\text { Serum potassium } \\
(\geq 4 \mathrm{mEq} / \mathrm{l} \mathrm{vs} .<4 \mathrm{mEq} / \mathrm{l})\end{array}$ & I.278(I.073-I.662) & 0.03 \\
\hline $\begin{array}{l}\text { Ejection fraction } \\
(\geq 50 \% \text { vs. }<50 \%)\end{array}$ & I.48I (0.737-I.55I) & 0.32 \\
\hline $\begin{array}{l}\text { Diabetes (present } \\
\text { vs. absent) }\end{array}$ & 1.331 (1.109-1.5I7) & 0.04 \\
\hline $\begin{array}{l}\text { Multi-vessel disease } \\
\text { (present vs. absent) }\end{array}$ & $0.316(0.030-71.482)$ & 0.68 \\
\hline
\end{tabular}

c) inhibition of free radical formation from vascular endothelial cells and macrophages; d) inhibition of vascular smooth muscle cell proliferation; and e) suppression of reactive oxygen species overproduction [23].

Such established findings are in contradiction to two previous studies [ I , 12] which have reported that hyperkalemia is associated with increased atherosclerosis. Multiple factors can affect serum potassium levels including renal function, dietary intake, hormonal status, renin-angiotensin-aldosterone system, heart failure, myocardial infarction and drugs. The major limitation in the study conducted by Cavusoglu et al. [II] was that they only included subjects of the male gender. Diane et al. [24] previously reported that male sex was associated with higher potassium levels as compared to females. This could have clearly affected the results obtained by Cavusoglu and his research team.

In the second study conducted by Guang et al. [12] the study group has no patients with myocardial infarction. Although studies have shown that in acute stress such as myocardial infarction, the potassium level is higher due to various mechanisms involving necrosis induced activation of aldosterone system and sympathetic-adrenal induced involvement of sodium-potassium pumps [25-27]. But by the exclusion of such group from the study also means that patients with more severe could not be assessed for the observed results.

We, in our study, not only included subjects of both genders but also myocardial infarction patients along with patients of chronic and stable coronary artery disease. We believe such a study group would a better understanding of patients in real-life situation. Moreover, we in our study not only assessed severity of coronary atherosclerosis not only by Gensini score which assesses the severity of coronary vasculature on the anatomical basis and has been described elsewhere [19], but also SYNTAX score which is well-established sys- tem for quantification of coronary lesions as well as for prediction of major adverse cardiac events (MACE) in patients undergoing percutaneous coronary intervention $(\mathrm{PCl})[18,28-30]$. Such measures were taken in order to ensure more reliable and comprehensive results.

\section{Limitations}

It is a single centered study and was not designed to interpret results based on ethnicity and dietary habits. Selecting a large population with multi-centered study would address such concerns.

\section{Conclusion}

Serum potassium level is lower in coronary artery disease and is correlated with severity of atherosclerosis on coronary angiography. Serum potassium is an independent predictor of adverse outcomes in coronary artery disease patients.

\section{Acknowledgement of grant support}

This research did not receive any specific grant from funding agencies in the public, commercial, or not-forprofit sectors.

\section{Conflict of interest:}

None.

\section{References:}

I. American Heart Association. Heart disease and stroke statistics: 2005 Update. Dallas, Tex: American Heart Association. 2004.

2. Sica DA, Struthers AD, Cushman WC, et al. Importance of potassium in cardiovascular disease. J Clin Hypertens (Greenwich). 2002; 4(3): 198-206, doi: 10.1 III/j.1524-6175.2002.01728.x, indexed in Pubmed: 12045369.

3. Smith PD, Brett SE, Luykenaar KD, et al. KIR channels function as electrical amplifiers in rat vascular smooth muscle. J Physiol. 2008; 586(4): II47-II60, doi: 10.1 I |3/jphysiol.2007.145474, indexed in Pubmed: 18063660.

4. Jin CZi, Kim HS, Seo EY, et al. Exercise training increases inwardly rectifying $\mathrm{K}(+)$ current and augments $\mathrm{K}(+)$-mediated vasodilatation in deep femoral artery of rats. Cardiovasc Res. 20I I; 91(I): 142-150, doi: 10.1093/cvr/cvr050, indexed in Pubmed: 21349874.

5. Haddy FJ, Vanhoutte PM, Feletou M. Role of potassium in regulating blood flow and blood pressure. Am J Physiol Regul Integr Comp Physiol. 2006; 290(3): R546-R552, doi: 10.1152/ ajpregu.00491.2005, indexed in Pubmed: 16467502.

6. Seo EY, Kim HJ, Zhao ZH, et al. Low K. current in arterial myocytes with impaired K-vasodilation and its recovery by exercise in hypertensive rats. Pflugers Arch. 2014; 466(II): 210I-2III, doi: 10.1007/s00424-014-1473-7, indexed in Pubmed: 245577I3.

7. Young DB, Lin H, McCabe RD. Potassium's cardiovascular protective mechanisms. Am J Physiol. 1995; 268(4 Pt 2): R825- 
R837, doi: 10.1152/ajpregu. 1995.268.4.R825, indexed in Pubmed: 7733391.

8. Ando K, Matsui H, Fujita M, et al. Protective effect of dietary potassium against cardiovascular damage in salt-sensitive hypertension: possible role of its antioxidant action. Curr Vasc Pharmacol. 2010; 8(I): 59-63, doi: 10.2174//570|6| I079022656I, indexed in Pubmed: 19485915.

9. Tobian L, Jahner TM, Johnson MA. High K diets markedly reduce atherosclerotic cholesterol ester deposition in aortas of rats with hypercholesterolemia and hypertension. Am J Hypertens. 1990; 3(2): 133-135, doi: 10.1093/ajh/3.2.133, indexed in Pubmed: 2306340.

10. Zhang Y, Zhu CG, Guo YL, et al. Higher fibrinogen level is independently linked with the presence and severity of new-onset coronary atherosclerosis among $\mathrm{Han}$ Chinese population. PLoS One. 20 I4; 9(I I): el I3460, doi: 10.1371/journal.pone.01 I3460, indexed in Pubmed: 25426943.

II. Cavusoglu E, Chopra V, Gupta A. Relation of baseline serum potassium levels to angiographic findings in patients with known or suspected coronary artery disease. Am J Hypertens. 2009; 22: 754-762.

12. Guang Xian Zhao, Xiang Lan Jin, Ji Long Kang, Chun Zi Jin. Serum potassium levels are associated with coronary artery lesion severity in coronary artery disease. Int J Clin Exp Med. 2016; 9(2): 3705-3710.

13. Thygesen K, Alpert JS, Jaffe AS, et al. Joint ESC/ACCF/AHA/ WHF Task Force for the Universal Definition of Myocardial Infarction. Third universal definition of myocardial infarction. Circulation. 2012; 126(16): 2020-2035, doi: 10.1/6I/CIR. 0b013e31826el058, indexed in Pubmed: 22923432.

14. Catapano AL, Graham I, De Backer G, et al. ESC Scientific Document Group. 2016 ESC/EAS Guidelines for the Management of Dyslipidaemias. Eur Heart J. 2016; 37(39): 2999-3058, doi: 10. 1093/eurheartj/ehw272, indexed in Pubmed: 27567407.

15. Williams B, Mancia G, Spiering W, et al. Authors/Task Force Members:, ESC Scientific Document Group . 2018 ESC/ESH Guidelines for the management of arterial hypertension. Eur Heart J. 2018; 39(33): 3021-3104, doi: 10.1093/eurheartj/ ehy339, indexed in Pubmed: 30165516.

16. https://www.health.govt.nz/our-work/preventative health wellness/tobacco control/tobacco-control information-practitioners/definitions smoking-status.

17. https://www.medscape.com/answers/80279-119321/what is the seldinger technique for femoral central venous access and how is it performed.

18. Palmerini T, Genereux P, Caixeta A, et al. Prognostic value of the SYNTAX score in patients with acute coronary syndromes undergoing percutaneous coronary intervention: analysis from the ACUITY (Acute Catheterization and Urgent Intervention Triage StrategY) trial. J Am Coll Cardiol. 201 I; 57(24): 2389-2397, doi: 10.1016/j.jacc.2011.02.032, indexed in Pubmed: 21658558.
19. Gensini GG. A more meaningful scoring system for determining the severity of coronary heart disease. Am J Cardiol. 1983; 5I(3): 606, doi: $10.1016 / 50002-9149(83) 80105-2$, indexed in Pubmed: 6823874.

20. Ahn MJ, Kim MC, Ahn Y, et al. Impact of Complete Revascularization on Six-Year Clinical Outcomes and Incidence of Acute Decompensated Heart Failure in Patients With ST-Segment Elevation Myocardial Infarction and Multivessel Coronary Artery Disease. Am J Cardiol. 2018; 121(5): 544-55I, doi: 10.1016/j. amjcard.2017.11.025, indexed in Pubmed: 29325904.

21. Franse LV, Pahor M, Di Bari M, et al. Hypokalemia associated with diuretic use and cardiovascular events in the Systolic Hypertension in the Elderly Program. Hypertension. 2000; 35(5): 1025-1030, doi: 10.1161/01.hyp.35.5.1025, indexed in Pubmed: 10818057.

22. Tobian L. Protecting arteries against hypertensive injury. Clin Exp Hypertens A. 1992; 14(I-2): 35-43, doi: 10.3109/10641969209036/69, indexed in Pubmed: I541045.

23. $\mathrm{Li} X, \mathrm{Li} Y$, Jin J, et al. Increased serum cathepsin $\mathrm{K}$ in patients with coronary artery disease. Yonsei Med J. 20I4; 55(4): 912 -919, doi: 10.3349/ymj.2014.55.4.912, indexed in Pubmed: 24954318

24. Wysowski DK, Kornegay C, Nourjah P, et al. Sex and age differences in serum potassium in the United States. Clin Chem. 2003; 49(I): 190-192, doi: 10.1373/49.1.190, indexed in Pubmed: 12507983.

25. Goyal A, Spertus JA, Gosch K, et al. Serum potassium levels and mortality in acute myocardial infarction. JAMA. 2012; 307(2): 157-164, doi: 10.1001/jama.2011.1967, indexed in Pubmed: 22235086

26. Sekiyama H, Nagoshi T, Komukai K. et.al. Transient decrease in serum potassium level during ischemic attack of acute coronary syndrome: paradoxical contribution of plasma glucose level and glycohemo $\neg$ globin. Cardiovasc Diabetol. 2013; 12 : 4.

27. Zhang $\mathrm{H}$, Zhou CY. and Fu HY. The level of potassium in early patients with acute myocardial infarction and the analysis of its relevant factors. Chinese Journal of Prevention and Control of Chronic Diseases. 20II; 3: 026.

28. Sianos G, Morel MA, Kappetein AP, et al. The SYNTAX Score: an angiographic tool grading the complexity of coronary artery disease. Eurolntervention. 2005; I (2): 219-227, indexed in Pubmed: 19758907.

29. Serruys PW, Onuma Y, Garg S, et al. Assessment of the SYNTAX score in the Syntax study. Eurolntervention. 2009; 5(I): 50-56, doi: 10.4244/eijv5ila9, indexed in Pubmed: 19577983.

30. Kato S, Saito N, Kirigaya $H$, et al. Incremental prognostic value of the SYNTAX score to late gadolinium-enhanced magnetic resonance images for patients with stable coronary artery disease. Heart Vessels. 2016; 31(6): 87I-880, doi: 10.1007/ s00380-015-0685-x, indexed in Pubmed: 25904244. 